\title{
What determines success in Initial Coin Offerings?
}

\author{
Abe de Jong \\ Monash University and Rotterdam School of Management, Erasmus University \\ Peter Roosenboom* \\ Rotterdam School of Management, Erasmus University \\ Tom van der Kolk \\ Rotterdam School of Management, Erasmus University
}

\begin{abstract}
In this paper, we analyse the determinants of success for 630 ICOs performed between August 2015 and December 2017. We find evidence that ICOs are more successful in raising funding when they disclose more information to investors (i.e. have higher transparency rating), have a higher quality rating by cryptocurrency experts, organise a presale, have a preICO GitHub repository, refrain from offering bonus schemes, have shorter planned token sale durations and have a larger project team. Depending on the measure used, these ICOs also have improved ex-post performance. We conclude that for entrepreneurs it is important to make the ICO as transparent as possible and that expert ratings are a valuable means to overcome the information asymmetry problems associated with token sales.
\end{abstract}

JEL Codes: G24, G32

Keywords: Initial Coin Offerings; token sales; entrepreneurial finance

* Corresponding author. Finance Department, Rotterdam School of Management, Erasmus University. Burgemeester Oudlaan 50, 3062 PA Rotterdam, The Netherlands. Email: proosenboom@rsm.nl, Phone: +31 104081255. 


\section{Introduction}

Initial Coin Offerings (ICOs) have become an increasingly popular way to raise capital for blockchain technology startups. In an ICO, entrepreneurs raise money for their venture by selling newly created cryptocurrency tokens to investors in exchange for fiat currency such as US dollars or cryptocurrencies such as Ethereum or Bitcoin (Chohan, 2017; Kastelein, 2017). At the time of the ICO, the project is mostly at the idea stage and the actual launch of the product or service is expected within one to two years after the ICO (EY, 2017). The cryptocurrency tokens typically act as a digital medium of exchange to access the firm's digital platform and services. After completing the ICO, the tokens can be traded on an online exchange and increase in value with the success of the project. One advantage for entrepreneurs is that ICOs allow them to raise capital by selling tokens rather than shares and therefore do not require them to give up ownership and control rights to investors as would be the case with venture capital or equity-based crowdfunding.

The total amount of funding through ICOs in 2017 equalled $\$ 5.38$ billion, surpassing early-stage venture capital investments in blockchain startups (Sunnarborg, 2017) and \$12 billion in the 16 months since January 2017 (Benedetti and Kostovetsky, 2018). Some blockchain startups have been able to raise capital via token sales at record speed, largely because of investors' fear of missing out (also known as FOMO). For example, the company Gnosis was able to raise $\$ 12$ million in less than 10 minutes (Cointelegraph, 2017). At the same time, the number of blockchain startups reaching their maximum fundraising goal has declined since the last quarter of 2017 and regulators are pointing out the risks associated with largely unregulated ICOs such as fraud, exaggeration of expected returns and lack of transparency (EY, 2017; SEC, 2017).

In this paper, we aim to answer the question why some projects succeed in raising funding in ICOs and get their tokens listed on CoinmarketCap, a leading website for tracking exchange-traded cryptocurrencies, whereas others do not. In our analysis, we include both uncapped and capped ICOs. In an uncapped ICO the token supply is not limited or the token price is not known beforehand. This contrasts with capped ICOs in which the company sells a limited supply of tokens at a fixed priced. The vast majority of ICOs are capped. In a capped ICO the company may set two funding goals: a minimum fundraising goal (softcap) as well as a maximum fundraising goal (hardcap). The company only keeps the money it has raised in case the amount raised exceeds the pre-set softcap ("all-or-nothing"). Once the softcap has been reached the company keeps all the money it raises even if the hardcap has not been 
reached ("keep-it-all"). In our analyses we use several dependent variables to measure funding success in order to reflect the different ways ICOs can be structured: a binary variable indicating whether the ICO reaches its softcap (if any), the amount of money raised as a percentage of the hardcap (only in capped ICOs), the log of the amount of money raised in the ICO, and a binary variable indicating whether the ICO is tracked on CoinmarketCap.

In addition, we look beyond funding success and also investigate whether the project is successful afterwards or has ended up on what Varshneya (2018) calls the "digital graveyard". We investigate whether the projects survive up to July 2018. We use four measures of ex-post success: whether the project has recently been active on Twitter, the number of Tweets per week since the ICO commenced, whether the project has recently updated its repositories on the software development platform GitHub and whether the project's website is still online in July 2018. We employ a large sample of 630 capped and uncapped ICOs from August 2015 until December 2017. We stop in December 2017 in order to measure success as survival for a period of at least half a year. Our results show that ICOs with a higher transparency and expert rating are more successful in raising funds and perform better in the post-ICO period. We find evidence that having a pre-ICO GitHub repository, organising a presale for early investors, a shorter planned token sale duration, not having a bonus scheme, and having a larger project team is positively associated to fundraising success and depending on the measure used, also to ex-post project success. Moreover, the percentage of tokens retained by the project team is positively related to two of our measures of ex-post performance.

Our paper adds to the literature on entrepreneurial finance and the emerging literature on ICOs. Existing studies on ICOs model the choice between ICO and venture capital funding (Catalini and Gans, 2018; Chod and Lyandres, 2018), investigate the need for legislation of ICOs (Kaal, 2018), the geography of ICOs (Huang, Meoli and Vismara, 2018), the liquidity and trading volume of exchange-traded ICOs (Howell, Niessner and Yermack, 2018) and returns to investors in ICOs (Benedetti and Kostovetsky, 2018). We are aware of three other (working) papers on the determinants of funding success of ICOs. First, Adhami, Giudici and Martinazzi (2018) investigate 253 ICOs from 2014 until August 2017 of which 81 percent reaches the softcap. They find that ICOs are more likely to reach the softcap in case their programming code is (partially) available in an online GitHub repository (measured after the ICO), when the company has presold tokens to early-stage investors and when tokens come with the right to access services or in some cases to a share in the profits. Second, Fisch (2018) examines 238 ICOs in 2016 and 2017. He finds that the dollar amount 
raised in the ICO is positively impacted by a larger token supply, having a cryptocurrency token that is Ethereum-based, and the number of endorsements (stars) received on programming code repository GitHub (measured after the ICO). Third, Amsden and Schweizer (2018) look at the large sample of 1,009 ICOs (573 of which have data on funding amounts) from 2015 until March 2018 and use token tradability on CoinmarketCap as their main success measure. They report that venture uncertainty is negatively correlated with success while venture quality has a positive impact on ICO success.

We extend the thin literature on ICOs fourfold. First, we investigate a number of previously unexplored determinants (most importantly, expert and transparency ratings, GitHub presence measured at the time of the ICO, and planned ICO duration in days). Second, we use various fundraising success measures that distinguish between capped versus uncapped ICOs and take into account the softcap and hardcap fundraising goals. Also, we use a funding success measure that captures whether the ICO is trading on an exchange recognized by CoinmarketCap, a tracking website for exchange-traded cryptocurrencies. Adhami et al. (2018) only look at whether the softcap has been reached and Fisch (2018) merely uses the log of the amount raised as the dependent variable. Amsden and Schweizer (2018) use token tradability as their key measure of success. Third, we make use of the largest slice of the ICO universe for which data is available. We use eleven ICO databases ${ }^{1}$ to obtain this data, as no single database covers the full ICO universe. One issue that all ICO studies face is that many of the ICOs that end up being unsuccessful delete their data. These ICOs are thus less likely to be included in the analysis. However, we only miss out on a few unsuccessful ICOs. Our sample includes 630 out of the 682 ICOs listed on ICObench, a respected rating website for ICOs, during our sample period. This allows us to paint a more comprehensive picture of the determinants of fundraising success in ICOs compared to these previous studies. Fourth, we extend the existing papers on ICO funding success by adding an analysis of ex-post success of ICOs.

The remainder of this paper is structured as follows. Section 2 discusses ICOs in more detail. Section 3 derives our hypotheses. We describe our sample in Section 4. Section 5 presents our results. We conclude in Section 6.

\section{A primer on ICOs}

\footnotetext{
${ }^{1}$ Databases accessed: www.tokendata.io, www.icotracker.net, www.cryptocompare.com/ico, www.smithandcrown.com/icos, https://elementus.io/token-sales-history, www.icomarketdata.com, www.icodata.io, www.coindesk.com/ico-tracker/, www.icobench.com/ico, www.coinschedule.com, www.ico-list.com, www.icostats.com
} 
Cryptocurrencies are digital assets that can be used as a medium of exchange, using cryptography to secure and verify transactions. Tokens are a type of cryptocurrency representing an asset or utility, without creating a new blockchain or protocol. Instead, these tokens reside on top of another blockchain such as Bitcoin or Ethereum. Tokens are used in most ICO campaigns and ICOs are therefore sometimes referred to as token sales. The first ever ICO was launched in 2013 when Mastercoin (currently called Omni), was able to raise over 5000 Bitcoins, at that time worth $\$ 500,000$ (Jaffe, 2018). The crowdsale of Ethereum in 2014 raised \$18 million and has been very influential in shaping the present-day ICO landscape, as many applications are based on its blockchain. Ethereum created a new decentralised platform that incorporated smart contracts. Smart contracts are pre-written computer protocols that can be executed by the distributed ledger technology itself. It allows for entirely self-executing clauses from a contract, without any party verifying or performing the contract (Rosic, 2017). The most commonly used one for raising capital is ERC-20, a smart contract that creates a new cryptocurrency token and allows for transferring cryptocurrency from one person to another. This unique capability allows developers to build a wide variety of innovative applications on top of the Ethereum blockchain, becoming the most popular blockchain for ICOs (The Economist, 2017).

In 2017, one of the first uncapped ICOs ran into trouble. Tezos raised $\$ 232$ million in its uncapped ICO but soon after faced several class-action suits accusing the company of selling unregistered securities, misrepresenting on how funds would be spent, misrepresenting when the platform would go live, false advertising, and engaging in misleading trade practices. This triggered criticism regarding 'uncapped sale' models, a model that does not pre-specify the maximum about of funding raised during the ICO and in which entrepreneurs would only set a start and end-date, awaiting the number of coins that would be bought by investors. According to critics the uncapped model shows greed of the promoters trying to sell as many tokens as possible and provides a significant concern for investors as they expose themselves to high uncertainty about the cryptocurrency valuation (Buterin, 2017). Because of this, ICOs have more often become 'capped', predetermining the number of tokens for sale before ICO launch and setting a fixed price for the tokens. However, capped ICOs are more likely to be oversubscribed in case of strong investor interest, resulting in a more substantial incentive for investors to getting in first out of Fear of Missing Out (FOMO). Examples of successfully capped token sales are BAT and Gnosis, which were sold out 30 seconds and 10 minutes respectively (Buterin, 2017). 
Since the inception of ICOs, regulators have expressed concerns about fraud, lack of transparency, and lack of investor protection. Unlike traditional shareholders, investors in ICOs often have no control over the project or its promotors (Kaal, 2018). However, at the time of writing only a few countries explicitly prohibit ICO campaigns. Most countries are using existing laws to regulate cryptocurrencies or assume a reactive stance by awaiting other countries' actions before taking regulatory actions themselves. The chairman of the SEC, Jay Clayton, recently argued that some ICOs constitute the sale of securities and should, therefore, be registered with and regulated by the SEC (Marks, 2018). Several blockchain projects create a not-for-profit foundation in e.g., Switzerland or offshore corporations in, for example, the Cayman Islands, Gibraltar or Singapore to avoid taxation on the ICO proceeds. Huang, Meoli and Vismara (2018) examine the geography of ICOs and find that ICOs primarily come from countries with developed financial markets and advanced digital technologies.

The ICO process starts with a pre-announcement on several relevant cryptocurrency forums (i.e. Reddit, Bitcointalk) and contains an executive summary of the projects' objectives, team members and most notable features of the product. At this pre-ICO phase, tokens are sold privately to early bird investors who receive bonuses for investing during the presale. This allows the project developers to test market demand and estimate a price for the token. Comments made by early bird investors are considered when drafting the whitepaper, a document that contains more in-depth information about the project to support later investors in their decision-making process (Kaal and Dell'Erba, 2017; Yadav, 2017). Nowadays, more sophisticated blockchain ventures also publish a yellow paper, or a second whitepaper, that details the (in many cases tested and peer-reviewed) technology and innovations the venture has created or plans to create. However, companies that launch an ICO campaign face no mandatory disclosures. Whitepapers issued at the time of the ICO tend to be very technical and difficult to read for most investors and the content of the whitepaper has little if any impact on fundraising success (Fisch, 2018). Whitepapers are not audited or certified by any authority (Deloitte, 2017) and sometimes even lack the justification for using blockchain technology (EY, 2017).

At the launch of the ICO, the project team announces the starting date of the public token sale. Typically, a marketing campaign is set up to address a broader group of potential investors (including smaller retail investors), playing a crucial role in the success of a campaign. Subsequently, the project team launches the public ICO and releases the cryptocurrencies. As there is no regulation concerning ICO structure, there are numerous 
possibilities for project developers in the design of the campaign. For example, the project developers can opt for a capped versus uncapped sale, make use of minimum fundraising goals (softcaps) and/or maximum fundraising goals (hardcaps) and accept payment in fiat currency and/or (multiple) digital currencies (Buterin, 2017). The initial value and supply of the tokens are entirely at the discretion of the project developers, and often arbitrarily determined. Also, similar to the presale, some ventures reward early investors in the public ICO with free tokens or discounts.

When an ICO is completed, the tokens will be available for trading usually two weeks after the end of the funding campaign. Benedetti and Kostovetsky (2018) find that tokens are on average underpriced by $179 \%$ from the ICO price to the opening price on the first trading day to compensate investors for the high risks associated with investing in ICOs. Currently, there are more than 40 exchanges, serving as secondary markets, available for cryptocurrency trading (Lea, 2017). Depending on the relation between the project developers and management of the cryptocurrency exchange, a newly issued token is listed. Often, project teams should pay a fee to register their cryptocurrency on an exchange - with higher costs for higher volumes. Howell et al. (2018) report that liquidity and trading volume of exchangetraded tokens are higher when project developers disclose more information about the project, show a strong commitment to the project and signal quality.

\section{Hypotheses development}

Information asymmetry is one important barrier to the financing of early-stage ventures (Chod and Lyandres, 2018). At the time of the ICO, there are no compulsory or audited disclosures and the project is mostly at the idea stage with the actual launch of the product or service only expected within one to two years after the ICO (EY, 2017). Moreover, there is no or little regulation and investor protection. In theory, this context would impair successful fundraising by blockchain technology startups.

The two typical asymmetric information problems of adverse selection (hidden information) and moral hazard (hidden action) plague the relationship between project developers and potential investors respectively before ("ex-ante") and after ("ex-post") the ICO. The first information problem of hidden information or adverse selection (Akerlof, 1970) cannot be addressed by high-quality ICOs simply stating that they are of the highquality type. Also, a low-quality ICO could (falsely) claim to be of the high-quality type and therefore investors would ignore this "cheap talk". Another possibility is to fully disclose 
information directly to potential investors. Investors use several information sources to assess the quality of the token sale such as GitHub, Twitter, Telegram/Slack/Discord, Bitcoinwiki, Facebook, Bitcointalk, whitepapers, videos, and LinkedIn. We hypothesize that voluntary disclosure acts as a quality signal. Project teams of high-quality projects are more willing to disclose information whereas project teams of poor quality projects are less willing to share information with potential investors, especially when they face penalties if the disclosure proves to be fraudulent ex-post (e.g., see the theoretical model of Hughes, 1986). We hypothesize:

Hypothesis 1A: More extensive disclosure (i.e., a higher transparency rating) has a positive influence on fundraising success

Hypothesis 1B: More extensive disclosure (i.e., a higher transparency rating) has a positive influence on subsequent project success

At the same time, projects might be hesitant to share technical proprietary information in whitepapers or in a public GitHub repository with a wider circle of investors. Moreover, at the time of the ICO, the product or service still needs to be developed and intellectual property rights by patents and/or trademarks are not (yet) in place. Also, the technical information in whitepapers seems difficult to comprehend by most investors in ICOs and most investors do not have the time and expertise to conduct a due diligence of the project themselves. One solution to this problem is to make use of ratings by experts. In the cryptosphere, a respected rating website, consisting of experts who voluntarily review ICOs, is ICObench. To become an expert one must show a thorough knowledge of cryptocurrencies and its underlying market dynamics. Reviewers obtain no compensation. ${ }^{2}$ We expect that highly rated ICOs are more likely to be successful in raising funds and in the period after the ICO. Therefore, we hypothesise that:

Hypothesis 2A: Higher ratings by expert reviewers have a positive influence on fundraising success

Hypothesis 2B: Higher ratings by expert reviewers have a positive influence on subsequent project success

\footnotetext{
${ }^{2}$ https://medium.com/@ICObench/icobench-experts-the-importance-of-being-just-bbe07e00f73e
} 
Another way to mitigate the adverse selection problem is signaling (Spence, 1973). In the case of signaling the project deliberately makes use of positive and observable indicators of otherwise not directly observable qualities in an attempt to mitigate the ex-ante information problem with investors (Spence, 2002). In order to be effective, a signal needs to be costly and correlate strongly with the quality it plans to indicate. High-quality ICOs are better able to absorb the higher costs of signaling. Low-quality projects will not imitate the signal of high-quality projects because they are not able or willing to bear the high costs associated with the signal. The benefits of being correctly identified as a high-quality ICO would outweigh the high costs only in case the project is truly of the high-quality type. The decision to post the programming code underlying the project on software development platform and repository GitHub can be seen as such a signal. It would allow experts to review the programming code and information about the technical side of the project before the ICO and collaborate on further improving it also in the period after the ICO. Only companies that are confident about the technical side of their project would subject it to expert scrutiny on GitHub before the ICO. We hypothesize:

Hypothesis 3A: Posting programming code or technical information on software repository GitHub before the ICO has a positive influence on fundraising success Hypothesis 3B: Posting programming code or technical information on software repository GitHub before the ICO has a positive impact on subsequent project success

The distribution of tokens to insiders may be another important signal to investors. In ICOs, the percentage of tokens owned by the insiders after the ICO is known at the time of the ICO. These exchange-traded tokens can be sold in the future at a higher price in case the project is successful and needs to raise fresh capital. This signals that project developers are confident about the future success of the project and refrain from raising as much capital as possible from gullible investors at the time of the ICO. The percentage of tokens held by insiders may also mitigate the ex-post information or moral hazard problem. If insiders continue to own a significant percentage of the tokens they have a strong incentive to work hard towards a successful launch the blockchain project.

Hypothesis 4A: A higher percentage of tokens retained by insiders positively impacts fundraising success 
Hypothesis 4B: A higher percentage of tokens retained by insiders positively impacts subsequent project success

An ICO can take place in multiple stages, i.e. a pre-ICO can be launched to test market demand and estimate a price for the token. Before opening the ICO to the public, early bird investors are typically able to obtain bonuses (e.g. deep discounts for early investors without lockups or vesting periods) to encourage early participation and to generate momentum. Typically there is a higher minimum investment amount compared to the public sale that follows afterwards. The ICO presale tends to be smaller than the public phase of the ICO and is intended to show to the public that the project team was able to have a pool of (befriended) cornerstone investors willing to invest in the project already.

Hypothesis 5: ICOs preceded by a presale are more likely to successfully raise funds in the public phase of the ICO

The public ICO follows suit, is open for everyone to invest in, and often has a lower minimum investment amount compared to the presale. Early investors in public token sales can also qualify for bonuses and price discounts albeit lower compared to the presale. This creates an incentive for investors to invest as soon as possible out of fear of missing out. However, having to make use of bonus schemes in the public phase of the ICO may also signal that the project team is struggling to attract sufficient interest in the presale (if organized) or in the ICO itself and that, despite the bullish market for ICOs in our sample period, it needs to resort to bonuses and price discounts to attract public investors. Moreover, potential investors may be afraid that too many bonus participants can engage in flipping and sell the tokens at a profit (at ICO price) once the tokens launch on a secondary market, driving the price down. We hypothesize that the use of bonus schemes in the public part of the ICO has a negative effect:

Hypothesis 6: The use of bonus schemes in the public phase of the ICO negatively impacts fundraising success

At the launch of the ICO, the project team announces the number of days the campaign will accept funding. In the context of reward-based crowdfunding, Mollick (2014) reports that campaigns with a longer duration have a lower probability of reaching their funding goals. 
Planning on a longer duration may signal a lack of confidence in the project to potential investors (Mollick, 2014). We, therefore, hypothesize that a longer planned duration of the ICO campaign at the time of its launch negatively impacts fundraising success.

Hypothesis 7: Longer planned campaign durations have a negative influence on fundraising success

Investors may appreciate larger project teams, as it may show that a larger number of people are willing to work on bringing the project to fruition, speeding up the time to the actual launch of the blockchain project. Ahlers, Cumming, Gunther and Schweizer (2015) show that human capital (proxied by the number of board members) is positively related to funding success on one of the first crowdinvestment platforms, the Australian Small Scale Offerings Board. In addition, a larger project team implies a larger network of contacts it can mobilize to promote the ICO and assist in the project's future development. We hypothesize:

Hypothesis 8A: Having a larger project team positively impacts fundraising success Hypothesis 8B: Having a larger project team positively impacts subsequent project success

\section{Data and methods}

We start with an initial dataset consisting of 682 ICOs from ICObench and other sources during the period August 2015 until December $2017^{3}$. We stop in December 2017 in order to measure success as survival for a period of at least half a year. Because information is widely dispersed on the internet and most databases often include only partial information, we identify these ICOs from eleven databases. ${ }^{4}$ Out of the available databases, ICObench provides the most thorough and highest quality information on ICO campaigns and therefore serves as the core of our sample. By using the Application Programming Interface (API), it is possible to draw information from the database directly. Even though we consider ICObench the most comprehensive database, it still lacks key information which we manually complemented with data from other databases, websites, forum threads and whitepapers.

\footnotetext{
${ }^{3}$ See: https://icobench.com/stats

${ }^{4}$ Databases accessed: www.tokendata.io, www.icotracker.net, www.cryptocompare.com/ico,

www.smithandcrown.com/icos, https://elementus.io/token-sales-history, www.icomarketdata.com, www.icodata.io, www.coindesk.com/ico-tracker/, www.icobench.com/ico, www.coinschedule.com, www.ico-list.com, www.icostats.com
} 
For 52 out of 682 ICOs, it is not possible to find relevant information on the Internet, because websites, forum posts and Twitter accounts have been deleted or never took place. In case insufficient data is available online, we exclude the ICO from the dataset. In a handful of cases where we could not obtain the amounts of capital raised directly from ICObench or other sources, we have analysed the transactions on the blockchain during the ICO period to calculate the funding amount ourselves. ${ }^{5}$ This resulted in a sample consisting of 630 ICOs.

In our analyses we use four measures of funding success as our dependent variables, reflecting the different ways in which ICOs are structured. Table 1 shows the variable definitions. Table 2 provides an overview of the ICO distribution (country of origin, project category and blockchain used) in our sample. Table 3 presents the descriptive statistics. We measure funding success with a dummy variable indicating whether the softcap (i.e. the minimum funding goal) has been reached, the amount of capital raised as a percentage of the hardcap (i.e., the maximum funding goal), the log of the amount of capital raised, and a dummy variable indicating whether the ICO was admitted to trading on an online exchange that is tracked by CoinmarketCap. Table 3 shows that 185 ICOs make use of a softcap (29\% of the sample). The softcap averages $\$ 4.96$ million and 85 ICOs with softcaps ( $46 \%$ of the sample with softcaps) manage to raise more capital than the minimum target amount. Our sample contains 575 capped ICOs (91.3\% of the sample) and 55 uncapped ICOs (8.7\% of the sample). The average hardcap is set at $\$ 56.5$ million for the capped ICOs. On average, a capped ICO raises $34 \%$ of its hardcap. The average amount of capital raised amounts to $\$ 9.55$ million with a minimum of zero and a maximum of $\$ 258$ million. Cryptocurrencies more frequently accepted as payment are Ethereum (in 533 ICOs, $85 \%$ of the sample), followed by Bitcoin (in 184 ICOs, $29 \%$ of the sample). Fiat currency is only accepted in 41 ICOs $(6.5 \%$ of the sample). In our sample 163 ICOs accept multiple currencies as means of payment for the tokens ( $26 \%$ of the sample). Half of the ICOs in our sample are admitted to trading on an online exchange tracked by CoinmarketCap.

We also use four dependent variables to measure the success of the project afterwards. We look at whether the website of the project is still online in July 2018, the Tweets from the project team per week in the period between the start of the ICO and July 2018, whether there have been any Tweets by the project team in the period May until July 2018, and whether there any contributions on software repository GitHub during that same period. There are 518 project websites still online in July 2018 (82\% of the sample). The

\footnotetext{
${ }^{5}$ Using the following websites: www.etherscan.io, https://wavesexplorer.com, https://blockexplorer.com/
} 
average (median) Tweet activity of the project team equals 13.7 (7.06) Tweets per week during the period between the end of the ICO and July 2018. There are 387 projects with recent Tweets (70\% of 552 projects with Twitter accounts), and 181 projects with recent activity on GitHub (about half of the 357 projects with GitHub repositories at any point in time).

Our independent variables include the expert ratings and transparency ratings on rating website ICObench, a dummy variable indicating whether the project created a GitHub repository before the ICO (retrieved via a Chrome extension), the percentage of tokens retained by insiders, a dummy variable whether a presale takes place before the public phase of the ICO, a dummy variable indicating whether a bonus scheme is used in the public token sale, the planned duration of the ICO in days and the number of project team members. Table 3 documents that the average (median) expert rating on ICObench equals 3.39 (3.47). The highest possible rating is five, corresponding to high-quality ICOs, whereas the lowest possible score is one, implying a weak investment opportunity. The rating consists of three elements: team, vision and product, and is available for 311 observations. The expert rating is based on the review of an average of 2.7 cryptocurrency experts. The transparency rating is available for all ICOs in the dataset and yields an average (median) of 3.03 (3). This rating is based on a computer algorithm and reflects the disclosure on ICObench for 31 distinct elements, such as the presence of GitHub, Twitter, Facebook etc. (for an extensive description consult Table 1). There are 253 projects with GitHub software repositories at the time of the ICO (40\% of the sample). Insiders retain an average (median) of $42 \%(40 \%)$ of tokens. Presales happen in 241 cases (38.3\% of the sample) and bonus schemes such as price discounts and free tokens are used in the public part of the ICO in 252 ICOs (40\% of the sample). Table 3 shows that the average (median) duration of the ICO campaign is planned to be 29 days (30 days). The average (median) project team consists of 9.6 (8) members.

We include several control variables in our regressions. In regressions using the funding percentage as the dependent variable, we control for the log of the hardcap (i.e., the maximum funding goal). Mollick (2014) reports that higher funding goals reduce the likelihood of funding success for reward-based crowdfunding campaigns on Kickstarter. In regressions using the log of the funding amount as the dependent variable, we control for a dummy that indicates whether the ICO was uncapped or not. In uncapped ICOs, the investors are uncertain about how many tokens will be sold or about the cryptocurrency valuation. This could signal opportunistic behaviour or even greed on the part of the project developers as 
they sell as many tokens as investors want to buy (Buterin, 2017). In contrast, in capped ICOs the maximum amount of funding is fixed. There are 55 uncapped ICOs ( $8.7 \%$ of the sample).

In addition, we control for the token price (excluding any bonuses and price discounts) and the log of the number of tokens created (i.e. the total of tokens that are sold and held by insiders). Investors might be more interested in tokens with lower prices and lower supply because they anticipate a more upward potential for these lower priced and scarce tokens. The average (median) token price equals $\$ 17.9$ but the median token price equals only 26 dollar cents. The average (median) number of tokens created amounts to more than 20 billion (100 million). The large difference between average and median values indicates the presence of outliers. Therefore, we log transform the variables token price and token supply. Furthermore, we include the number of accepted currencies for payment, a dummy variable indicating if paying with fiat currency was possible and a dummy variable related to whether the project is (partly) based on the Ethereum platform as control variables in our models.

In the next section, we report our regression results. In case of binary dependent variables we make use of logistic regressions, otherwise OLS regressions are used.

\section{Results}

\subsection{Transparency and expert ratings}

In this section, we examine the effect of transparency and expert ratings on funding and expost success measures. We start with a univariate analysis presented in Table 4. Panel A shows the funding and ex-post success measures split by the transparency rating categories (ranging from 0 to 5). Panel $\mathrm{B}$ displays these success measures split by expert rating categories (ranging from1 to 5). A clear pattern emerges showing that both higher transparency and expert ratings are associated with more funding as well as better ex-post project performance. Table 4 also shows the difference in means between ICOs with a transparency or expert rating above the median or below the median. Regarding funding success, ICOs with an above median transparency and expert rating are significantly more successful in reaching the softcap and raise more capital (both expressed as a percentage of the hardcap as well as the dollar amount) compared to ICOs with below median transparency or expert ratings. ICOs with an above median transparency and expert ratings are also more likely to have their tokens listed on CoinmarketCap than ICOs with a below median score on 
these ratings. For ex-post success, Table 4 shows that ICOs with above median ratings perform superior compared to below median rated token sales. We find that ICOs with an above median transparency and expert rating have a significantly higher likelihood of their website being online in July 2018 and are more likely to have post-ICO Twitter and GitHub activity in the period between May and July 2018. The number of Tweets per week in the period from the start of the ICO until July 2018 is significantly higher for ICOs with above median transparency ratings compared to the ICOs with below median scores. However, we do not find a significant difference in the number of Tweets per week when comparing the ICOs with above and below median expert ratings even though the smaller categories with the lowest rating (up to 3) clearly have fewer Tweets.

Next, we conduct multivariate regression analyses. Table 5 shows that the transparency and expert rating have a positive and highly significant impact on funding success, both when run separately (Panels A and B) and jointly in a regression (Panel C) together with time dummies. The only exception relates to the expert rating which is no longer significantly associated with the probability of reaching the softcap target amount in Panel $\mathrm{C}$ of Table 5 . However, it should be noted that the number of observations in the other models is much higher. The effects are both statistically and economically important: for example, in the second column of Table 5 we find that a one-point increase in the transparency or the expert rating will increase the funding percentage by more than ten percentage-points.

Table 6 shows the effect of the transparency and expert ratings on ex-post success measures. We find that both types of ratings matter and have a positive and significant impact on how well the project performs in the post-ICO period. Only the expert rating loses its significance in the regression using Tweets per week as the dependent variable (Panel C), which is consistent with our univariate results.

In line with our first two hypotheses, our results show that both transparency and expert ratings are statistically and economically important determinants of funding and expost project success. These ratings serve as aggregated measures on the transparency and quality of ICOs and each is an important determinant in its own right. In the next subsection, we further delve into the underlying determinants of success.

\subsection{Success determinants}


In this section, we investigate several determinants that, based on theory, we expect to impact funding and/or ex-post project performance (see Section 3). It is important to note that in our multivariate analyses we do not include the ratings. The reason is that many of the success determinants we look at are also components of the ratings (also see our variable description in Table 1). For example, the availability of a pre-ICO GitHub repository is also part of the transparency rating. None of the regressions in Tables 8 and 9 suffer from multicollinearity problems (Variance Inflation Factors are below two).

As in the previous section, we start with a univariate analysis. Table 7 shows that, on average, a significantly higher fraction of ICOs reaches its softcap in case the project has one or more GitHub repositories at the time of the ICO, it has a below median duration, and an above median number of project team members. On average, an ICO raises a higher percentage of its hardcap, raises more money and is more likely to trade on an online exchange in case there is at least one pre-ICO GitHub repository, an above median retention of tokens by the project team, a below median planned duration of the campaign, and an above median number of people participating in the project team. ICOs with a bonus scheme in the public phase of the ICO experience less funding success on average. We find no statistical difference in average funding success between ICOs with and without a presale.

Regarding the ex-post success measures, we find that, on average, a higher fraction of projects have their website online in July 2018 and generate more Tweets per week when they have one or more GitHub repositories at the launch of their ICO, the project team retains a percentage of tokens above the sample median and the project team has an above median number of team members. We report that fewer ICOs have their website online in July 2018 in case they offered bonuses to investors in the public phase of the token sale. A higher fraction of projects have recent Twitter and GitHub activity when they have above median token retention by insiders, they do not offer a bonus scheme, a planned duration of their campaign below the sample median, and their team consists of an above median number of members. On average, a higher fraction of projects has recent Twitter activity in case they have one or more GitHub repositories at the launch of their ICO.

The multivariate results using the four funding success measures as the dependent variable are presented in Table 8. The first column shows that having a presale, a shorter planned duration and a higher number of team members positively impact the probability of hitting the softcap target amount. Funding as a percentage of the hardcap target amount, the amount of funding and the probability of getting the token traded on an online exchange are all positively impacted by having one or more GitHub repositories before the ICO, having a 
presale but not having a bonus scheme in the public phase of the ICO, having a shorter planned duration of the campaign, and having more members on the project team. These findings are in line with our hypotheses 3A, 5, 6, 7 and 8A. However, in contrast with our hypothesis $4 \mathrm{~A}$ insider token retention is insignificant. Considering the control variables, we observe that setting a higher target amount for the softcap reduces the probability of reaching that target and a setting a higher target amount for the hardcap negatively impacts funds raised as a percentage of that hardcap. These findings are in line with Mollick (2014) who finds similar results in the context of reward-based crowdfunding. In some model specifications, we also find the fiat currency dummy, the Ethereum dummy and the total token supply to be significant.

The multivariate results using the four ex-post success measures are reported in Table 9. The number of team members positively impacts all ex-post performance measures, consistent with hypothesis $8 \mathrm{~B}$. There is some support for Hypotheses $3 \mathrm{~B}$ and 4B. Pre-ICO GitHub repositories are positively associated with the probability of having the project's website online in July 2018 and the project team being active on Twitter in the period May until July 2018. Token retention by the project team is positively related to GitHub activity in the period May until July 2018 as well as the number of Tweets per week in the period from the ICO start until July 2018.

Although we did not develop specific hypotheses concerning the ex-post performance for the other dependent variables, we do find that ICO campaigns that have been open for funding for a shorter period of time generate more Tweets in the period from the start of the ICO until July 2018 and are more likely to still be active on Twitter and GitHub in the period of May until July 2018. ICOs with a bonus scheme in the public phase of the selling process are associated with a lower probability of having the website online and Twitter activity in the period of May until July 2018. Several of the control variables (fiat currency dummy, token price and total token supply) are significant in some model specifications.

We have also conducted several additional analyses (unreported). We have included dummies for the countries and categories listed in Table 2. Our results are robust to the inclusion of these dummies. Instead of time dummies, we controlled for investor sentiment by either the log of the number of ICOs in the month of the token sale or the volatility and return of Ethereum in the month preceding the month in which the ICO commenced. Our results are robust to controlling for these investor sentiment measures.

\section{Conclusions}


Initial Coin Offerings (ICOs) have become an increasingly popular way for entrepreneurs to raise money for early-stage blockchain projects. ICOs are fraught with asymmetric information problems between the project team vis-à-vis potential investors that are considering buying the tokens. This paper is the first to test whether ratings from rating websites such as ICObench can help to bridge this information gap. We find that projects that disclose more extensive information to investors (i.e. have a higher transparency rating) are more successful in fundraising and experience more post-ICO project success. In addition, a higher rating by cryptocurrency experts on the quality of the project and project team is associated with more success in fundraising and better ex-post performance.

Our results further show that having one or more pre-ICO GitHub repository, a presale, not making use of bonus schemes in the public phase of the ICO, a shorter planned duration of the ICO campaign, and a larger project team are positively related to funding success. Depending on model specification, we also find that having at least one GitHub repository at the time of the ICO, the percentage of tokens retained by the project team, not having a bonus scheme in the public part of the ICO, a shorter planned period during which tokens are sold, and a larger number of project team members positively impact ex-post project performance.

We conclude that for entrepreneurs it is important to make the ICO as transparent as possible and that, also for investors, expert ratings are a useful way in which to overcome the information asymmetry problems associated with token sales. Project teams that provide more and useful information to investors are more likely to successfully raise money from investors and perform superior afterwards.

Our research demonstrates that in the ICO setting economic theory provides meaningful determinants of success, including disclosure and ratings that can reduce the information gap. However, we also demonstrate many elements that are specific to ICOs with strong effects on the success in raising funding and sustaining the business. Although our study presents tests of hypotheses and detailed information on the ICOs, future research will be needed to build theory specifically for ICOs, as well as empirical work assessing the longer-term viability of ICO-funded businesses. 


\section{References}

Adhami, S., Giudici, G., \& Martinazzi, S., 2018, "Why do businesses go crypto? An empirical analysis of Initial Coin Offerings", Journal of Economics and Business, forthcoming.

Ahlers, G. K., Cumming, D., Günther, C., and Schweizer, D., 2015, "Signaling in equity Crowdfunding", Entrepreneurship Theory and Practice 39, 955-980.

Akerlof, G. A., 1970, "The market for "Lemons": Quality uncertainty and the market mechanism", Quarterly Journal of Economics 84, 488-500.

Amsden, R. and Schweizer D., 2018, Are blockchain crowdsales the new 'gold rush'? Success determinants of Initial Coin Offerings. Available at SSRN: https://papers.ssrn.com/sol3/papers.cfm?abstract_id=3163849

Benedetti, H. and Kostovetsky, L., 2018, Digital tulips? Returns to investors in Initial Coin Offerings. Available at https://papers.ssrn.com/sol3/papers.cfm?abstract_id=3182169.

Buterin, V., 2017, Analyzing Token Sale Models. Available at: http://vitalik.ca/general/2017/06/09/sales.html. Accessed: 16 February 2018.

Catalini, C. and Gans, J.S., 2018, Initial Coin Offerings and the value of crypto tokens. Available at SSRN: https://papers.ssrn.com/sol3/papers.cfm?abstract_id=3143343.

Chod, J., and Lyandres, E., 2018, A theory of ICOs: Diversification, agency and information asymmetry. Available at SSRN: https://papers.ssrn.com/sol3/papers.cfm?abstract_id=3159528.

Chohan, U.W., 2017, Initial Coin Offerings (ICOs): Risks, regulation, and accountability, Discussion Paper Series: Notes on the 21st Century. Available at SSRN: https://ssrn.com/abstract=3080098.

Cointelegraph, 2017, Fastest-Ever ICO: Ethereum-based Gnosis creates $\$ 300$ million in minutes, raising $\$ 12$ million. Available at https://cointelegraph.com/news/fastestever-ico-ethereum-based-gnosis-creates-300-mln-in-minutes-raising-12-mln.

Accessed: 13 February 2018.

EY, 2017, EY Research: Initial Coin Offerings (ICOs). Report.

Fisch, C., 2018, Initial Coin Offerings (ICOs) to finance new ventures: An exploratory study. Available at SSRN: https://ssrn.com/abstract=3147521

Howell, S.T., Niessner, M. and Yermack, D., 2018, Initial Coin Offerings: Financing growth with cryptocurrency token sales. Available at SSRN: https://papers.ssrn.com/sol3/papers.cfm?abstract_id=3201259.

Huang, W., Meoli, M. and Vismara, S., 2018, The geography of Initial Coin Offerings. Available at SSRN: https://papers.ssrn.com/sol3/papers.cfm?abstract_id=3206234.

Hughes, P.J., 1986, "Signalling by direct disclosure under asymmetric information", Journal of Accounting and Economics 8, 119-142.

Jaffe, J., 2018, Initial Coin Offerings, Explained. CNET. Available at: https://www.cnet.com/how-to/initial-coin-offerings-explained/. Accessed: 17 February 2018.

Kaal, W., 2018, Initial Coin Offerings: The top 25 jurisdictions and their comparative regulatory responses. Available at SSRN: https://ssrn.com/abstract=3117224.

Kaal, W., and Dell'Erba, M., 2017, Initial Coin Offerings: Emerging practices, risk factors, and red flags. Forthcoming in F. Möslein \& S. Omlor (Eds.), Fintech Handbook, Verlag C.H. Beck.

Kastelein R., 2017, What Initial Coin Offerings are, and why VC firms care. Harvard Business Review. Available at: https://hbr.org/2017/03/what-initial-coin-offeringsare-and-why-vc-firms-care. Accessed: 30 January 2018. 
Lea T., 2017, Venture Capital 3.0: The Initial Coin Offering explained. AFR Online. Available at: http://www.afr.com/technology/venture-capital-30-the-initial-coinoffering-explained-20170502-gvxhos. Accessed: 20 February 2018.

Marks, H., 2018, The ICO is dead: Long live the ICO 2.0. Available at: https://hackernoon.com/the-ico-is-dead-long-live-the-ico-2-0-7bb269987513. Accessed: 10 June 2018.

Mollick, E., 2014, "The dynamics of crowdfunding: An exploratory study", Journal of Business Venturing 29, 1-16.

Rosic, A, 2017, Smart Contracts: The Blockchain technology that will replace lawyers. Available at: http://blockgeeks.com/guides/smart-contracts/. Accessed: 16 February 2018.

SEC, 2017, Investor Bulletin: Initial Coin Offerings. Available at: https://www.sec.gov/oiea/investor-alerts-and-bulletins/ib_coinofferings. Accessed 25 January 2018.

Spence, M., 1973, “Job market signaling”, Quarterly Journal of Economics 87, 355-374.

Spence, M., 2002, "Signaling in retrospect and the informational structure of markets", American Economic Review 92, 434-459.

Sunnarborg, A., 2017, ICO investments pass VC funding in blockchain market first. Coindesk. Available at: https://www.coindesk.com/ico-investments-pass-vcfunding-in-blockchain-market-first/. Accessed: 18 February 2018.

The Economist, 2017, The market in Initial Coin Offerings risks becoming a bubble. Volume 413, issue 9034, 29 April 2017.

Varshneya, R., 2018, Should you launch an ICO to raise money for your startup? Available at: https://www.entrepreneur.com/article/315873. Accessed: 10 June 2018.

Yadav, M., 2017, Exploring signals for investing in an Initial Coin Offering (ICO). Available at SSRN: https://ssrn.com/abstract=3037106. 
Table 1: Variable definitions

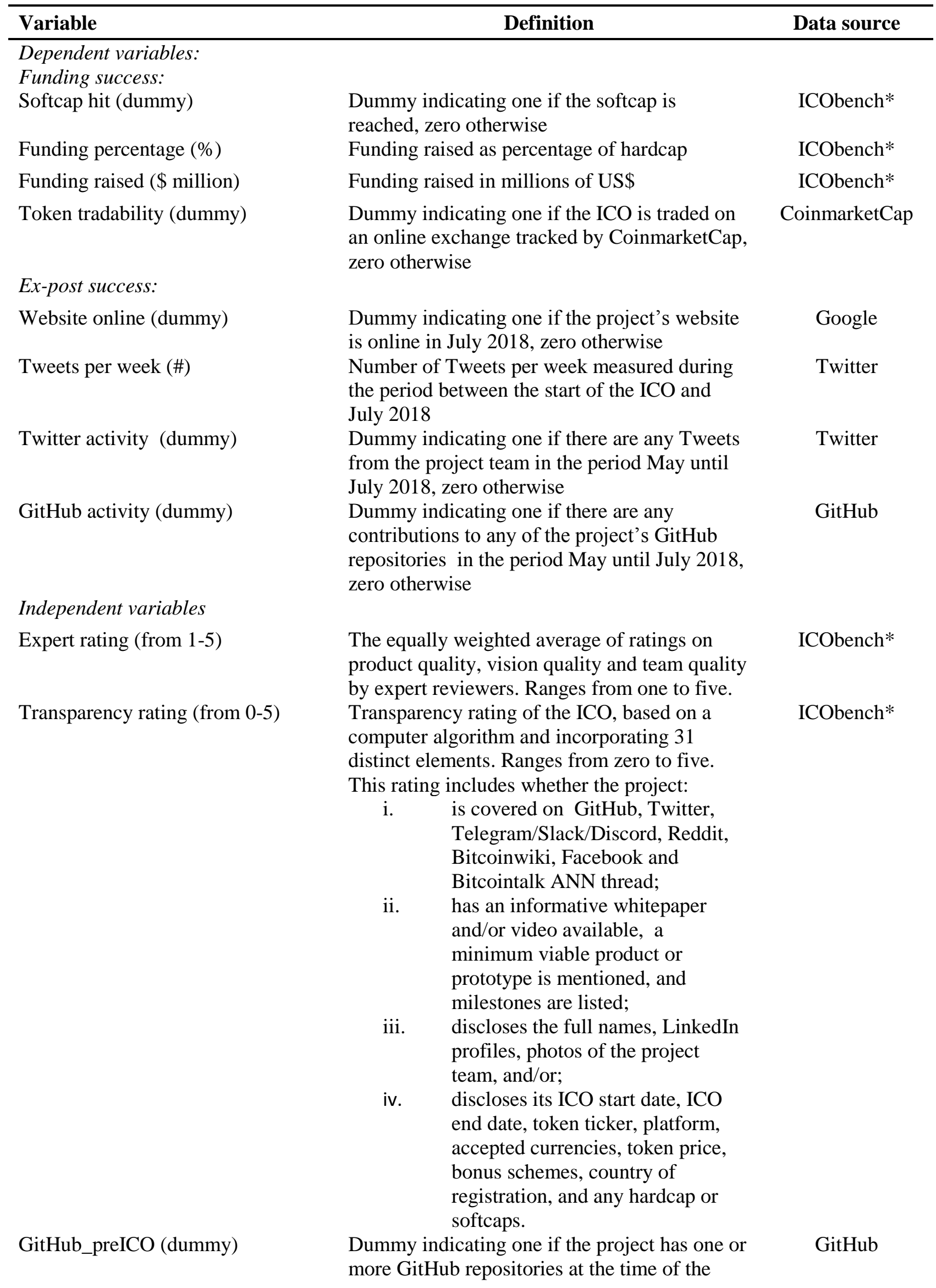


Insider token retention (\%)

Presale (dummy)

Bonus scheme (dummy)

Duration (\# days)

Team members (\#)

Control variables

Softcap (\$ million)

Hardcap (\$ million)

Uncapped ICO (dummy)

Accepted currencies (\#)

Fiat currency (dummy)

Ethereum platform (dummy)

Token price (\$ cents)

Total tokens (in millions)
ICO, zero otherwise

Percentage of tokens retained by the project

ICObench* team

Dummy indicating one if there is a presale of ICObench* tokens to early bird investors, zero otherwise Dummy indicating one if there is a bonus scheme (discounts and/or free tokens) in the public phase of the ICO, zero otherwise

Number of planned for the ICO campaign at the time of its launch

Number of members of the project team

ICObench*

ICObench*

ICObench*

Softcap target amount in millions of US dollars ICObench*

Hardcap target amount in millions of US ICObench*

dollars

Dummy indicating one if the ICO is uncapped, ICObench*

zero otherwise

Number of accepted cryptocurrencies that are ICObench* accepted as payment for the tokens

Dummy indicating one if a fiat currency (e.g. ICObench* US dollars) can be used as payment for the tokens, zero otherwise

Dummy indicating one if the project is (partly) ICObench* based on the Ethereum blockchain, zero otherwise Token price in US dollar cents ICObench*

Total number of tokens after ICO in millions ICObench* (circulating and retained)

Note: * In case data was missing on ICObench, it is complemented by using information from additional sources such as: www.tokendata.io, www.icotracker.net, www.cryptocompare.com/ico, www.smithandcrown.com/icos, https://elementus.io/token-sales-history, www.icomarketdata.com, www.icodata.io, www.coindesk.com/ico-tracker/, www.icobench.com/ico, www.coinschedule.com, www.ico-list.com, www.icostats.com. Additionally, we consulted the whitepaper, website, Bitcointalk forum thread, Telegram, Twitter and Facebook of the ICO to complement missing data. 
Table 2: Sample distribution

\begin{tabular}{|c|c|c|c|c|c|c|c|c|}
\hline \multicolumn{3}{|c|}{ Country } & \multicolumn{3}{|c|}{ Category } & \multicolumn{3}{|c|}{ Blockchain } \\
\hline & Count & $\%$ & & Count & $\%$ & & Count & $\%$ \\
\hline USA & 121 & 19.2 & Platform & 166 & 26.3 & Ethereum & 533 & 84.6 \\
\hline Russia & 85 & 13.5 & Currency & 100 & 15.8 & Waves & 39 & 6.2 \\
\hline UK & 47 & 7.4 & $\begin{array}{l}\text { Business } \\
\text { services }\end{array}$ & 66 & 10.5 & BitShares & 5 & 0.8 \\
\hline Singapore & 42 & 6.7 & Entertainment & 45 & 7.1 & NEO & 4 & 0.6 \\
\hline Switzerland & 27 & 4.3 & Investment & 31 & 4.9 & NEM & 3 & 0.5 \\
\hline Canada & 17 & 2.7 & Software & 31 & 4.9 & Omni & 3 & 0.5 \\
\hline Estonia & 14 & 2.2 & Banking & 28 & 4.4 & Counterparty & 2 & 0.3 \\
\hline Australia & 13 & 2.1 & $\begin{array}{l}\text { Casino \& } \\
\text { gambling }\end{array}$ & 18 & 2.9 & Litecoin & 2 & 0.3 \\
\hline Germany & 11 & 1.7 & Internet & 15 & 2.4 & NXT & 2 & 0.3 \\
\hline Hong Kong & 11 & 1.7 & Real estate & 15 & 2.4 & Ardor & 1 & 0.2 \\
\hline Israel & 11 & 1.7 & Other & 14 & 2.2 & Electroneum & 1 & 0.2 \\
\hline Netherlands & 11 & 1.7 & Media & 11 & 1.7 & Expanse & 1 & 0.2 \\
\hline Slovenia & 11 & 1.7 & Health & 9 & 1.4 & $\begin{array}{l}\text { Filecoin } \\
\text { Network }\end{array}$ & 1 & 0.2 \\
\hline China & 8 & 1.3 & Tourism & 9 & 1.4 & Maidsafe & 1 & 0.2 \\
\hline Lithuania & 8 & 1.3 & Infrastructure & 8 & 1.3 & NEBL & 1 & 0.2 \\
\hline France & 7 & 1.1 & Sports & 8 & 1.3 & Own & 1 & 0.2 \\
\hline Japan & 7 & 1.1 & Communication & 7 & 1.1 & QRC & 1 & 0.2 \\
\hline Spain & 7 & 1.1 & Education & 7 & 1.1 & Tendermint & 1 & 0.2 \\
\hline Unknown & 60 & 9.5 & Retail & 7 & 1.1 & Unknown & 26 & 4.1 \\
\hline Other & 112 & 17.9 & Other & 35 & 5.7 & Other & 2 & 0.3 \\
\hline Total & 630 & & Total & 630 & & Total & 630 & \\
\hline
\end{tabular}


Table 3: Descriptive statistics

\begin{tabular}{|c|c|c|c|c|c|c|}
\hline Variable & Obs. & Mean & Median & Std. Dev. & Min & Max \\
\hline \multicolumn{7}{|l|}{ Dependent variables: } \\
\hline Softcap hit (dummy) & 185 & 0.46 & 0 & 0.5 & 0 & 1 \\
\hline Funding percentage (\%) & 575 & 34.24 & 14.14 & 39 & 0 & 100 \\
\hline Funding raised ( $\$$ million) & 630 & 9.55 & 1.98 & 23.8 & 0 & 258 \\
\hline Token tradability (dummy) & 630 & 0.5 & 1 & 0.5 & 0 & 1 \\
\hline \multicolumn{7}{|l|}{ Dependent variables: } \\
\hline \multicolumn{7}{|l|}{ Ex-post success: } \\
\hline Tweets per week (\#) & 552 & 13.7 & 7.06 & 23.67 & 0 & 210 \\
\hline Twitter activity (dummy) & 552 & 0.7 & 1 & 0.46 & 0 & 1 \\
\hline GitHub activity (dummy) & 357 & 0.5 & 1 & 0.5 & 0 & 1 \\
\hline \multicolumn{7}{|l|}{ Independent variables: } \\
\hline Quality rating (from 1-5) & 311 & 3.39 & 3.47 & 0.93 & 1 & 5 \\
\hline Transparency rating (from 0-5) & 630 & 3.03 & 3 & 1.03 & 0.6 & 5 \\
\hline GitHub_preICO (dummy) & 630 & 0.40 & 0 & 0.49 & 0 & 1 \\
\hline Insider token retention (\%) & 630 & 41.51 & 40 & 25.01 & 0 & 99 \\
\hline Presale (dummy) & 630 & 0.38 & 0 & 0.49 & 0 & 1 \\
\hline Bonus scheme (dummy) & 630 & 0.4 & 0 & 0.49 & 0 & 1 \\
\hline Duration (\# days) & 630 & 28.96 & 30 & 17.77 & 1 & 134 \\
\hline Team members (\#) & 630 & 9.58 & 8 & 7.54 & 1 & 57 \\
\hline \multicolumn{7}{|l|}{ Control variables: } \\
\hline Softcap (\$ million) & 185 & 4.96 & 2 & 7.93 & 0.3 & 51 \\
\hline Hardcap (\$ million) & 575 & 56.53 & 20 & 347 & 0.02 & 7801 \\
\hline Uncapped ICO (dummy) & 630 & 0.08 & 0 & 0.283 & 0 & 1 \\
\hline Accepted currencies (\#) & 630 & 1.59 & 1 & 1.36 & 1 & 13 \\
\hline Fiat currency (dummy) & 630 & 0.07 & 0 & 0.25 & 0 & 1 \\
\hline Ethereum platform (dummy) & 630 & 0.85 & 1 & 0.36 & 0 & 1 \\
\hline Token price (\$ cents) & 630 & $1,788.59$ & 25.91 & $30,480.48$ & 0.01 & 755,460 \\
\hline Total tokens (in millions) & 630 & 20,229 & 100 & 337,554 & 0.01 & $8,000,000$ \\
\hline
\end{tabular}

Note: See Table 1 for data definitions. 
Table 4: Univariate tests: Transparency and expert ratings

\begin{tabular}{|c|c|c|c|c|c|c|c|c|}
\hline $\begin{array}{l}\text { Panel A: } \\
\text { Transparency rating }\end{array}$ & $<=1$ & $\begin{array}{l}>1, \\
<=2\end{array}$ & $\begin{array}{l}>2, \\
<=3\end{array}$ & $\begin{array}{l}>3 \\
<=4\end{array}$ & $\begin{array}{l}>4, \\
<=5\end{array}$ & $\begin{array}{l}\text { Above } \\
\text { median }\end{array}$ & $\begin{array}{l}\text { Below } \\
\text { median }\end{array}$ & $\begin{array}{l}\text { Test for } \\
\text { difference }\end{array}$ \\
\hline \multicolumn{9}{|l|}{ Funding success } \\
\hline Softcap hit (dummy) & $\begin{array}{l}0 \\
(3)\end{array}$ & $\begin{array}{l}0.231 \\
(26)\end{array}$ & $\begin{array}{l}0.278 \\
(54)\end{array}$ & $\begin{array}{l}0.508 \\
(63)\end{array}$ & $\begin{array}{l}0.821 \\
(39)\end{array}$ & $\begin{array}{l}0.627 \\
(102)\end{array}$ & $\begin{array}{l}0.253 \\
(83)\end{array}$ & $5.45^{* * *}$ \\
\hline Funding percentage (\%) & $\begin{array}{l}24.772 \\
(9)\end{array}$ & $\begin{array}{l}22.765 \\
(97)\end{array}$ & $\begin{array}{l}25.370 \\
(184)\end{array}$ & $\begin{array}{l}37.226 \\
(176)\end{array}$ & $\begin{array}{l}55.406 \\
(109)\end{array}$ & $\begin{array}{l}44.179 \\
(285)\end{array}$ & $\begin{array}{l}24.480 \\
(290)\end{array}$ & $6.25 * * *$ \\
\hline Funding raised (millions \$) & $\begin{array}{l}0.932 \\
(12)\end{array}$ & $\begin{array}{l}3.341 \\
(111)\end{array}$ & $\begin{array}{l}9.022 \\
(204)\end{array}$ & $\begin{array}{l}10.252 \\
(186)\end{array}$ & $\begin{array}{l}16.144 \\
(117)\end{array}$ & $\begin{array}{l}12.527 \\
(303)\end{array}$ & $\begin{array}{l}6.796 \\
(327)\end{array}$ & $3.05 * * *$ \\
\hline Token tradability (dummy) & $\begin{array}{l}0.5 \\
(12)\end{array}$ & $\begin{array}{l}0.297 \\
(111)\end{array}$ & $\begin{array}{l}0.382 \\
(204)\end{array}$ & $\begin{array}{l}0.565 \\
(186)\end{array}$ & $\begin{array}{l}0.812 \\
(117)\end{array}$ & $\begin{array}{l}0.660 \\
(303)\end{array}$ & $\begin{array}{l}0.358 \\
(311)\end{array}$ & $7.94 * * *$ \\
\hline \multicolumn{9}{|l|}{ Ex-post success } \\
\hline Website online (dummy) & $\begin{array}{l}0.417 \\
(12)\end{array}$ & $\begin{array}{l}0.613 \\
(111)\end{array}$ & $\begin{array}{l}0.809 \\
(204)\end{array}$ & $\begin{array}{l}0.887 \\
(186)\end{array}$ & $\begin{array}{l}0.983 \\
(117)\end{array}$ & $\begin{array}{l}0.924 \\
(303)\end{array}$ & $\begin{array}{l}0.728 \\
(327)\end{array}$ & $6.65 * * *$ \\
\hline Tweets per week (\#) & $\begin{array}{l}0.663 \\
(6)\end{array}$ & $\begin{array}{l}4.700 \\
(86)\end{array}$ & $\begin{array}{l}10.878 \\
(177)\end{array}$ & $\begin{array}{l}16.338 \\
(170)\end{array}$ & $\begin{array}{c}21.689 \\
(113)\end{array}$ & $\begin{array}{l}18.474 \\
(283)\end{array}$ & $\begin{array}{l}8.674 \\
(269)\end{array}$ & $4.97 * * *$ \\
\hline Twitter activity (dummy) & $\begin{array}{l}0.167 \\
(6)\end{array}$ & $\begin{array}{l}0.407 \\
(86)\end{array}$ & $\begin{array}{l}0.588 \\
(177)\end{array}$ & $\begin{array}{l}0.829 \\
(170)\end{array}$ & $\begin{array}{l}0.938 \\
(113)\end{array}$ & $\begin{array}{l}0.873 \\
(283)\end{array}$ & $\begin{array}{l}0.520 \\
(269)\end{array}$ & $9.78 * * *$ \\
\hline GitHub activity (dummy) & $\begin{array}{l}0.400 \\
(5)\end{array}$ & $\begin{array}{l}0.452 \\
(31)\end{array}$ & $\begin{array}{l}0.375 \\
(104)\end{array}$ & $\begin{array}{l}0.548 \\
(124)\end{array}$ & $\begin{array}{l}0.624 \\
(93)\end{array}$ & $\begin{array}{l}0.581 \\
(217)\end{array}$ & $\begin{array}{l}0.393 \\
(140)\end{array}$ & $3.51 * * *$ \\
\hline Panel B: Expert rating & $=1$ & $\begin{array}{l}>1, \\
<=2\end{array}$ & $\begin{array}{l}>2, \\
<=3\end{array}$ & $\begin{array}{l}>3, \\
<=4\end{array}$ & $\begin{array}{l}>4, \\
<=5\end{array}$ & $\begin{array}{l}\begin{array}{l}\text { Above } \\
\text { median }\end{array} \\
\end{array}$ & $\begin{array}{l}\text { Below } \\
\text { median }\end{array}$ & $\begin{array}{l}\text { Test for } \\
\text { difference }\end{array}$ \\
\hline \multicolumn{9}{|l|}{ Funding success } \\
\hline Softcap hit (dummy) & $\begin{array}{l}0 \\
(1)\end{array}$ & $\begin{array}{l}0.143 \\
(7)\end{array}$ & $\begin{array}{l}0.438 \\
(32)\end{array}$ & $\begin{array}{l}0.714 \\
(35)\end{array}$ & $\begin{array}{l}0.591 \\
(22)\end{array}$ & $\begin{array}{l}0.688 \\
(48)\end{array}$ & $\begin{array}{l}0.408 \\
(49)\end{array}$ & $2.85 * * *$ \\
\hline Funding percentage (\%) & $\begin{array}{l}28.125 \\
\text { (3) }\end{array}$ & $\begin{array}{l}13.805 \\
(24)\end{array}$ & $\begin{array}{l}22.593 \\
(74)\end{array}$ & $\begin{array}{l}39.495 \\
(120)\end{array}$ & $\begin{array}{l}65.529 \\
(69)\end{array}$ & $\begin{array}{l}54.727 \\
(141)\end{array}$ & $\begin{array}{l}24.375 \\
(149)\end{array}$ & $7.00 * * *$ \\
\hline Funding raised (millions \$) & $\begin{array}{l}1.125 \\
(4)\end{array}$ & $\begin{array}{l}4.274 \\
(26)\end{array}$ & $\begin{array}{l}9.400 \\
(79)\end{array}$ & $\begin{array}{l}11.457 \\
(123)\end{array}$ & $\begin{array}{l}20.914 \\
(79)\end{array}$ & $\begin{array}{l}17.151 \\
(153)\end{array}$ & $\begin{array}{l}8.200 \\
(158)\end{array}$ & $2.94 * * *$ \\
\hline Token tradability (dummy) & $\begin{array}{l}0.250 \\
(4)\end{array}$ & $\begin{array}{l}0.231 \\
(26)\end{array}$ & $\begin{array}{l}0.443 \\
(79)\end{array}$ & $\begin{array}{l}0.618 \\
(123)\end{array}$ & $\begin{array}{l}0.797 \\
(79)\end{array}$ & $\begin{array}{l}0.745 \\
(153)\end{array}$ & $\begin{array}{l}0.424 \\
(158)\end{array}$ & $6.05 * * *$ \\
\hline \multicolumn{9}{|l|}{ Ex-post success } \\
\hline Website online (dummy) & $\begin{array}{l}0.500 \\
(4)\end{array}$ & $\begin{array}{l}0.654 \\
(26)\end{array}$ & $\begin{array}{l}0.797 \\
(79)\end{array}$ & $\begin{array}{l}0.878 \\
(123)\end{array}$ & $\begin{array}{l}0.962 \\
(79)\end{array}$ & $\begin{array}{l}0.941 \\
(153)\end{array}$ & $\begin{array}{l}0.772 \\
(158)\end{array}$ & $4.35 * * *$ \\
\hline Tweets per week (\#) & $\begin{array}{l}0.739 \\
(4)\end{array}$ & $\begin{array}{l}7.241 \\
(22)\end{array}$ & $\begin{array}{l}10.481 \\
(74)\end{array}$ & $\begin{array}{c}19.941 \\
(113)\end{array}$ & $\begin{array}{l}18.803 \\
(76)\end{array}$ & $\begin{array}{l}17.886 \\
(143)\end{array}$ & $\begin{array}{l}14.127 \\
(146)\end{array}$ & 1.233 \\
\hline Twitter activity (dummy) & $\begin{array}{l}0.250 \\
(4)\end{array}$ & $\begin{array}{l}0.318 \\
(22)\end{array}$ & $\begin{array}{l}0.581 \\
(74)\end{array}$ & $\begin{array}{l}0.850 \\
(113)\end{array}$ & $\begin{array}{l}0.974 \\
(76)\end{array}$ & $\begin{array}{l}0.930 \\
(143)\end{array}$ & $\begin{array}{l}0.603 \\
(146)\end{array}$ & $7.08 * * *$ \\
\hline GitHub activity (dummy) & $\begin{array}{l}0 \\
(2)\end{array}$ & $\begin{array}{l}0.222 \\
(9)\end{array}$ & $\begin{array}{l}0.304 \\
(46)\end{array}$ & $\begin{array}{l}0.545 \\
(77)\end{array}$ & $\begin{array}{l}0.705 \\
(61)\end{array}$ & $\begin{array}{l}0.654 \\
(107)\end{array}$ & $\begin{array}{l}0.352 \\
(88)\end{array}$ & $4.38 * * *$ \\
\hline
\end{tabular}

Note: See Table 1 for variable definitions. Table reports averages. Number of observations is in parentheses. The last column shows a $t$-statistic for the test for difference in means. ${ }^{*}=$ significant at the $10 \%$ level, $* *=$ significant at the $5 \%$ level, $* * *=$ significant at the $1 \%$ level. 
Table 5: Determinants of funding success: Transparency and expert ratings

\begin{tabular}{|c|c|c|c|c|}
\hline Variable & Softcap hit & $\begin{array}{l}\text { Funding } \\
\text { percentage }\end{array}$ & $\begin{array}{c}\text { Ln(1+ } \\
\text { Funding } \\
\text { raised) }\end{array}$ & $\begin{array}{c}\text { Token } \\
\text { tradability }\end{array}$ \\
\hline \multicolumn{5}{|l|}{ Panel A } \\
\hline Transparency rating (from 0-5) & $\begin{array}{l}0.253 \\
(12.05)^{* * *}\end{array}$ & $\begin{array}{l}0.136 \\
(9.91)^{* * *}\end{array}$ & $\begin{array}{l}2.935 \\
(16.19) * * *\end{array}$ & $\begin{array}{l}0.186 \\
(13.27)^{* * *}\end{array}$ \\
\hline Time dummies & Yes & Yes & Yes & Yes \\
\hline Observations & 185 & 575 & 630 & 630 \\
\hline F-Value & & $36.03 * * *$ & $57.41 * * *$ & \\
\hline Wald $\mathrm{Chi}^{2}$ & $43.72 * * *$ & & & $133.19 * * *$ \\
\hline (pseudo or adjusted) R-Squared & 0.274 & 0.182 & 0.313 & 0.214 \\
\hline \multicolumn{5}{|l|}{ Panel B } \\
\hline Expert rating (from 1-5) & $\begin{array}{l}0.150 \\
(3.03)^{* * *}\end{array}$ & $\begin{array}{l}0.162 \\
(6.84)^{* * *}\end{array}$ & $\begin{array}{l}2.660 \\
(7.51)^{* * *}\end{array}$ & $\begin{array}{l}0.140 \\
(5.41)^{* * *}\end{array}$ \\
\hline Time dummies & Yes & Yes & Yes & Yes \\
\hline Observations & 97 & 290 & 311 & 311 \\
\hline F-Value & & $22.62 * * *$ & $17.95 * * *$ & \\
\hline Wald Chi ${ }^{2}$ & 9.03 & & & $62.79 * * *$ \\
\hline (pseudo or adjusted) R-Squared & 0.091 & 0.215 & 0.225 & 0.178 \\
\hline \multicolumn{5}{|l|}{ Panel C } \\
\hline Transparency rating (from 0-5) & $\begin{array}{l}0.296 \\
(8.54)^{* * *}\end{array}$ & $\begin{array}{l}0.120 \\
(6.21)^{* * *}\end{array}$ & $\begin{array}{l}2.834 \\
(10.47)^{* * *}\end{array}$ & $\begin{array}{l}0.171 \\
(7.85)^{* * *}\end{array}$ \\
\hline Expert rating (from 1-5) & $\begin{array}{l}-0.074 \\
(-1.38)\end{array}$ & $\begin{array}{l}0.112 \\
(4.30)^{* * *}\end{array}$ & $\begin{array}{l}1.397 \\
(4.48) * * *\end{array}$ & $\begin{array}{l}0.057 \\
(2.17) * *\end{array}$ \\
\hline Time dummies & Yes & Yes & Yes & Yes \\
\hline Observations & 97 & 290 & 311 & 311 \\
\hline F-Value & & $34.97 * * *$ & $33.53 * * *$ & \\
\hline Wald $\mathrm{Chi}^{2}$ & $25.73 * * *$ & & & $73.81 * * *$ \\
\hline (pseudo or adjusted) R-Squared & 0.325 & 0.287 & 0.441 & 0.284 \\
\hline
\end{tabular}

Note: See Table 1 for variable definitions. The first and fourth column report average marginal effects from logistic regressions with $z$-statistics using robust standard errors in parentheses. The second and third column report OLS regression coefficients with $t$-statistics using robust standard errors in parentheses. $*=$ significant at the $10 \%$ level, $* *=$ significant at the $5 \%$ level, $* * *=$ significant at the $1 \%$ level. 
Table 6: Determinants of ex-post success: Transparency and expert ratings

\begin{tabular}{|c|c|c|c|c|}
\hline Variable & $\begin{array}{c}\text { Website } \\
\text { online }\end{array}$ & $\begin{array}{c}\text { Tweets } \\
\text { per week }\end{array}$ & $\begin{array}{l}\text { Twitter } \\
\text { activity }\end{array}$ & $\begin{array}{l}\text { GitHub } \\
\text { activity }\end{array}$ \\
\hline \multicolumn{5}{|l|}{ Panel A } \\
\hline Transparency rating (from 0-5) & $\begin{array}{l}0.128 \\
(9.20)^{* * *}\end{array}$ & $\begin{array}{c}6.010 \\
(7.30)^{* * *}\end{array}$ & $\begin{array}{c}0.204 \\
(14.66)^{* * *}\end{array}$ & $\begin{array}{l}0.122 \\
(4.67) * * *\end{array}$ \\
\hline Time dummies & Yes & Yes & Yes & Yes \\
\hline Observations & 630 & 552 & 552 & 357 \\
\hline F-Value & & $14.00 * * *$ & & \\
\hline Wald $\mathrm{Chi}^{2}$ & $69.53 * * *$ & & $97.64 * * *$ & $24.73 * * *$ \\
\hline (pseudo or adjusted) R-Squared & 0.140 & 0.058 & 0.221 & 0.056 \\
\hline \multicolumn{5}{|l|}{ Panel B } \\
\hline Expert rating (from 1-5) & $\begin{array}{l}0.096 \\
(4.94)^{* * *}\end{array}$ & $\begin{array}{l}4.686 \\
(2.87)^{* * *}\end{array}$ & $\begin{array}{l}0.191 \\
(9.76)^{* * *}\end{array}$ & $\begin{array}{l}0.164 \\
(4.19) * * *\end{array}$ \\
\hline Time dummies & Yes & Yes & Yes & Yes \\
\hline Observations & 311 & 289 & 289 & 195 \\
\hline F-Value & & $2.22 *$ & & \\
\hline Wald $\mathrm{Chi}^{2}$ & $25.05 * * *$ & & $50.93 * * *$ & $20.54 * * *$ \\
\hline (pseudo or adjusted) R-Squared & 0.091 & 0.012 & 0.239 & 0.088 \\
\hline \multicolumn{5}{|l|}{ Panel C } \\
\hline Transparency rating (from 0-5) & $\begin{array}{l}0.106 \\
(6.01)^{* * *}\end{array}$ & $\begin{array}{l}5.822 \\
(5.16) * * *\end{array}$ & $\begin{array}{l}0.127 \\
(7.21)^{* * *}\end{array}$ & $\begin{array}{l}0.113 \\
(2.62)^{* * *}\end{array}$ \\
\hline Expert rating (from 1-5) & $\begin{array}{l}0.035 \\
(1.93)^{*}\end{array}$ & $\begin{array}{l}2.171 \\
(1.28)\end{array}$ & $\begin{array}{l}0.110 \\
(5.75)^{* * *}\end{array}$ & $\begin{array}{l}0.131 \\
(3.14)^{* * *}\end{array}$ \\
\hline Time dummies & Yes & Yes & Yes & Yes \\
\hline Observations & 311 & 289 & 289 & 195 \\
\hline F-Value & & $9.28 * * *$ & & \\
\hline Wald $\mathrm{Chi}^{2}$ & $47.80 * * *$ & & $57.18 * * *$ & $26.13 * * *$ \\
\hline (pseudo or adjusted) R-Squared & 0.220 & 0.050 & 0.354 & 0.117 \\
\hline
\end{tabular}

Note: See Table 1 for variable definitions. The first, third, and fourth column report average marginal effects from logistic regressions with $z$-statistics using robust standard errors in parentheses. The second column reports OLS regression coefficients with $t$-statistics using robust standard errors in parentheses. $*=$ significant at the $10 \%$ level, $* *=$ significant at the $5 \%$ level, $* * *=$ significant at the $1 \%$ level. 
Table 7: Univariate tests

\begin{tabular}{|c|c|c|c|c|c|c|c|c|c|}
\hline & \multicolumn{2}{|c|}{ PreICO_GitHub } & \multirow[b]{2}{*}{$\begin{array}{l}\text { Test for } \\
\text { difference }\end{array}$} & \multicolumn{2}{|c|}{$\begin{array}{c}\text { Insider token } \\
\text { retention }\end{array}$} & \multirow[b]{2}{*}{$\begin{array}{l}\text { Test for } \\
\text { difference }\end{array}$} & \multicolumn{2}{|c|}{ Presale } & \multirow[b]{2}{*}{$\begin{array}{l}\text { Test for } \\
\text { difference }\end{array}$} \\
\hline \multicolumn{3}{|l|}{ Funding success } & & $\begin{array}{l}\text { Above } \\
\text { median }\end{array}$ & $\begin{array}{l}\text { Below } \\
\text { or at } \\
\text { median }\end{array}$ & & Yes & No & \\
\hline Softcap hit (dummy) & $\begin{array}{l}0.542 \\
(72)\end{array}$ & $\begin{array}{l}0.407 \\
(113)\end{array}$ & $1.80^{*}$ & $\begin{array}{l}0.434 \\
(83)\end{array}$ & $\begin{array}{l}0.480 \\
(102)\end{array}$ & 0.63 & $\begin{array}{l}0.526 \\
(76)\end{array}$ & $\begin{array}{l}0.412 \\
(109)\end{array}$ & 1.53 \\
\hline $\begin{array}{l}\text { Funding percentage } \\
(\%)\end{array}$ & $\begin{array}{l}42.134 \\
(232)\end{array}$ & $\begin{array}{l}28.907 \\
(343)\end{array}$ & $4.04 * * *$ & $\begin{array}{l}37.907 \\
(264)\end{array}$ & $\begin{array}{l}31.134 \\
(311)\end{array}$ & $2.08 * *$ & $\begin{array}{l}35.043 \\
(230)\end{array}$ & $\begin{array}{l}33.711 \\
(345)\end{array}$ & 0.40 \\
\hline $\begin{array}{l}\text { Funding raised } \\
\text { (millions } \$ \text { ) }\end{array}$ & $\begin{array}{l}13.374 \\
(253)\end{array}$ & $\begin{array}{l}6.988 \\
(377)\end{array}$ & $3.33 * * *$ & $\begin{array}{l}13.002 \\
(291)\end{array}$ & $\begin{array}{l}6.592 \\
(339)\end{array}$ & $3.41 * * *$ & $\begin{array}{l}11.057 \\
(241)\end{array}$ & $\begin{array}{l}8.620 \\
(389)\end{array}$ & 1.25 \\
\hline $\begin{array}{l}\text { Token tradability } \\
\text { (dummy) }\end{array}$ & $\begin{array}{l}0.597 \\
(253)\end{array}$ & $\begin{array}{l}0.440 \\
(377)\end{array}$ & $3.89 * * *$ & $\begin{array}{l}0.546 \\
(291)\end{array}$ & $\begin{array}{l}0.466 \\
(339)\end{array}$ & $2.01 * *$ & $\begin{array}{l}0.490 \\
(241)\end{array}$ & $\begin{array}{l}0.512 \\
(389)\end{array}$ & 0.53 \\
\hline \multicolumn{10}{|l|}{ Ex-post success } \\
\hline $\begin{array}{l}\text { Website online } \\
\text { (dummy) }\end{array}$ & $\begin{array}{l}0.913 \\
(253)\end{array}$ & $\begin{array}{l}0.761 \\
(377)\end{array}$ & $4.97 * * *$ & $\begin{array}{l}0.852 \\
(291)\end{array}$ & $\begin{array}{l}0.796 \\
(339)\end{array}$ & $1.83 *$ & $\begin{array}{l}0.830 \\
(241)\end{array}$ & $\begin{array}{l}0.817 \\
(389)\end{array}$ & 0.39 \\
\hline Tweets per week (\#) & $\begin{array}{l}15.654 \\
(237)\end{array}$ & $\begin{array}{l}12.227 \\
(315)\end{array}$ & $1.69 *$ & $\begin{array}{l}17.344 \\
(254)\end{array}$ & $\begin{array}{l}10.591 \\
(298)\end{array}$ & $3.37 * * *$ & $\begin{array}{l}15.170 \\
(217)\end{array}$ & $\begin{array}{l}12.745 \\
(335)\end{array}$ & 1.18 \\
\hline $\begin{array}{l}\text { Twitter activity } \\
\text { (dummy) }\end{array}$ & $\begin{array}{l}0.781 \\
(237)\end{array}$ & $\begin{array}{l}0.641 \\
(315)\end{array}$ & $3.57 * * *$ & $\begin{array}{l}0.748 \\
(254)\end{array}$ & $\begin{array}{l}0.661 \\
(298)\end{array}$ & $2.23 * *$ & $\begin{array}{l}0.719 \\
(217)\end{array}$ & $\begin{array}{l}0.690 \\
(335)\end{array}$ & 0.73 \\
\hline $\begin{array}{l}\text { GitHub activity } \\
\text { (dummy) }\end{array}$ & $\begin{array}{l}0.482 \\
(253)\end{array}$ & $\begin{array}{l}0.567 \\
(104) \\
\end{array}$ & 1.46 & $\begin{array}{l}0.599 \\
(177)\end{array}$ & $\begin{array}{l}0.417 \\
(180) \\
\end{array}$ & $3.49 * * *$ & $\begin{array}{l}0.474 \\
(135) \\
\end{array}$ & $\begin{array}{l}0.527 \\
(222)\end{array}$ & 0.97 \\
\hline
\end{tabular}




\begin{tabular}{|c|c|c|c|c|c|c|c|c|c|}
\hline & \multicolumn{2}{|c|}{ Bonus scheme } & \multirow[b]{2}{*}{$\begin{array}{l}\text { Test for } \\
\text { difference }\end{array}$} & \multicolumn{2}{|c|}{ Duration } & \multirow[b]{2}{*}{$\begin{array}{l}\text { Test for } \\
\text { difference }\end{array}$} & \multicolumn{2}{|c|}{ Team members } & \multirow[b]{2}{*}{$\begin{array}{l}\text { Test for } \\
\text { difference }\end{array}$} \\
\hline \multicolumn{3}{|l|}{ Funding success } & & $\begin{array}{l}\text { Above } \\
\text { median }\end{array}$ & $\begin{array}{l}\text { Below } \\
\text { or at } \\
\text { median }\end{array}$ & & $\begin{array}{l}\text { Above } \\
\text { median }\end{array}$ & $\begin{array}{l}\text { Below } \\
\text { or at } \\
\text { median }\end{array}$ & \\
\hline Softcap hit (dummy) & $\begin{array}{l}0.413 \\
(92)\end{array}$ & $\begin{array}{l}0.505 \\
(93)\end{array}$ & -0.21 & $\begin{array}{l}0.370 \\
(73)\end{array}$ & $\begin{array}{l}0.518 \\
(112)\end{array}$ & $-1.98 * *$ & $\begin{array}{l}0.559 \\
(93)\end{array}$ & $\begin{array}{l}0.359 \\
(92)\end{array}$ & $2.78 * * *$ \\
\hline $\begin{array}{l}\text { Funding percentage } \\
(\%)\end{array}$ & $\begin{array}{l}25.163 \\
(236)\end{array}$ & $\begin{array}{l}40.565 \\
(339)\end{array}$ & $-4.75 * * *$ & $\begin{array}{l}23.647 \\
(231)\end{array}$ & $\begin{array}{l}41.359 \\
(344)\end{array}$ & $-5.47 * * *$ & $\begin{array}{l}39.796 \\
(279)\end{array}$ & $\begin{array}{l}29.010 \\
(296)\end{array}$ & $3.34 * * *$ \\
\hline $\begin{array}{l}\text { Funding raised } \\
\text { (millions \$) }\end{array}$ & $\begin{array}{l}6.079 \\
(252)\end{array}$ & $\begin{array}{l}11.868 \\
(378)\end{array}$ & $-3.01 * * *$ & $\begin{array}{l}6.019 \\
(254)\end{array}$ & $\begin{array}{l}11.940 \\
(376)\end{array}$ & $-3.09 * * *$ & $\begin{array}{l}14.287 \\
(304)\end{array}$ & $\begin{array}{l}5.137 \\
(326)\end{array}$ & $4.92 * * *$ \\
\hline $\begin{array}{l}\text { Token tradability } \\
\text { (dummy) }\end{array}$ & $\begin{array}{l}0.373 \\
(252)\end{array}$ & $\begin{array}{l}0.590 \\
(378)\end{array}$ & $-5.45 * * *$ & $\begin{array}{l}0.413 \\
(254)\end{array}$ & $\begin{array}{l}0.564 \\
(376)\end{array}$ & $-3.74 * * *$ & $\begin{array}{l}0.572 \\
(304)\end{array}$ & $\begin{array}{l}0.439 \\
(326)\end{array}$ & $3.38 * * *$ \\
\hline Ex-post success & & & & & & & & & \\
\hline $\begin{array}{l}\text { Website online } \\
\text { (dummy) }\end{array}$ & $\begin{array}{l}0.778 \\
(252)\end{array}$ & $\begin{array}{l}0.852 \\
(378)\end{array}$ & $-2.39 * *$ & $\begin{array}{l}0.799 \\
(254)\end{array}$ & $\begin{array}{l}0.838 \\
(376)\end{array}$ & 1.24 & $\begin{array}{l}0.914 \\
(304)\end{array}$ & $\begin{array}{l}0.736 \\
(326)\end{array}$ & $6.00 * * *$ \\
\hline Tweets per week (\#) & $\begin{array}{l}12.388 \\
(215)\end{array}$ & $\begin{array}{l}14.535 \\
(337)\end{array}$ & -1.04 & $\begin{array}{l}13.424 \\
(224)\end{array}$ & $\begin{array}{l}13.886 \\
(328)\end{array}$ & 0.82 & $\begin{array}{l}17.721 \\
(280)\end{array}$ & $\begin{array}{l}9.557 \\
(272)\end{array}$ & $4.11 * * *$ \\
\hline $\begin{array}{l}\text { Twitter activity } \\
\text { (dummy) }\end{array}$ & $\begin{array}{l}0.628 \\
(215)\end{array}$ & $\begin{array}{l}0.748 \\
(337)\end{array}$ & $-3.02 * * *$ & $\begin{array}{l}0.642 \\
(224)\end{array}$ & $\begin{array}{l}0.741 \\
(328)\end{array}$ & $2.48 * *$ & $\begin{array}{l}0.836 \\
(280)\end{array}$ & $\begin{array}{l}0.563 \\
(272)\end{array}$ & $7.33 * * *$ \\
\hline $\begin{array}{l}\text { GitHub activity } \\
\text { (dummy) }\end{array}$ & $\begin{array}{l}0.401 \\
(127)\end{array}$ & $\begin{array}{l}0.565 \\
(230)\end{array}$ & $-2.98 * * *$ & $\begin{array}{l}0.414 \\
(128)\end{array}$ & $\begin{array}{l}0.559 \\
(229)\end{array}$ & $2.64 * * *$ & $\begin{array}{l}0.553 \\
(206)\end{array}$ & $\begin{array}{l}0.444 \\
(151)\end{array}$ & $2.05 * *$ \\
\hline
\end{tabular}

Note: See Table 1 for variable definitions. Table reports averages. Number of observations is in parentheses. The last column shows a $t$-statistic for the test for difference in means. $*=$ significant at the $10 \%$ level, $* *=$ significant at the $5 \%$ level, $* * *=$ significant at the $1 \%$ level. 
Table 8: Determinants of funding success

\begin{tabular}{|c|c|c|c|c|}
\hline Variable & Softcap hit & $\begin{array}{c}\text { Funding } \\
\text { percentage }\end{array}$ & $\begin{array}{c}\text { Ln(1+ } \\
\text { Funding } \\
\text { raised) }\end{array}$ & $\begin{array}{c}\text { Token } \\
\text { tradability }\end{array}$ \\
\hline \multicolumn{5}{|l|}{ Independent variables } \\
\hline GitHub_preICO (dummy) & $\begin{array}{l}0.064 \\
(0.89)\end{array}$ & $\begin{array}{l}0.084 \\
(2.74)^{* * *}\end{array}$ & $\begin{array}{l}1.709 \\
(4.06)^{* * *}\end{array}$ & $\begin{array}{l}0.089 \\
(2.45)^{* *}\end{array}$ \\
\hline Insider token retention (\%) & $\begin{array}{l}-0.253 \\
(-1.57)\end{array}$ & $\begin{array}{l}0.038 \\
(0.61)\end{array}$ & $\begin{array}{l}0.225 \\
(0.26)\end{array}$ & $\begin{array}{l}0.113 \\
(1.42)\end{array}$ \\
\hline Presale (dummy) & $\begin{array}{l}0.197 \\
(3.03)^{* * *}\end{array}$ & $\begin{array}{l}0.066 \\
(2.11)^{* *}\end{array}$ & $\begin{array}{l}1.128 \\
(2.41)^{* *}\end{array}$ & $\begin{array}{l}0.106 \\
(2.77) * * *\end{array}$ \\
\hline Bonus scheme (dummy) & $\begin{array}{l}-0.114 \\
(-1.64)\end{array}$ & $\begin{array}{l}-0.082 \\
(-2.80) * * *\end{array}$ & $\begin{array}{l}-0.746 \\
(-1.70)^{*}\end{array}$ & $\begin{array}{l}-0.132 \\
(-3.81)^{* * *}\end{array}$ \\
\hline Duration (\# days) & $\begin{array}{l}-0.004 \\
(-1.66)^{*}\end{array}$ & $\begin{array}{l}-0.005 \\
(-6.69) * * *\end{array}$ & $\begin{array}{l}-0.025 \\
(-2.23) * *\end{array}$ & $\begin{array}{l}-0.006 \\
(-6.40)^{* * *}\end{array}$ \\
\hline Team members (\#) & $\begin{array}{l}0.019 \\
(2.19)^{* *}\end{array}$ & $\begin{array}{l}0.012 \\
(5.93)^{* * * *}\end{array}$ & $\begin{array}{l}0.228 \\
(8.14)^{* * *}\end{array}$ & $\begin{array}{l}0.013 \\
(4.42) * * *\end{array}$ \\
\hline \multicolumn{5}{|l|}{ Control variables } \\
\hline Softcap (log) & $\begin{array}{l}-0.085 \\
(-5.07) * * *\end{array}$ & & & \\
\hline Hardcap (log) & & $\begin{array}{l}-0.083 \\
(-5.27)^{* * *}\end{array}$ & & \\
\hline Uncapped ICO (dummy) & $\begin{array}{l}0.033 \\
(0.17)\end{array}$ & & $\begin{array}{l}0.033 \\
(0.04)\end{array}$ & $\begin{array}{l}0.032 \\
(0.52)\end{array}$ \\
\hline Accepted currencies (\#) & $\begin{array}{l}-0.002 \\
(-0.07)\end{array}$ & $\begin{array}{l}-0.006 \\
(-0.64)\end{array}$ & $\begin{array}{l}0.105 \\
(0.66)\end{array}$ & $\begin{array}{l}-0.006 \\
(-0.41)\end{array}$ \\
\hline Fiat currency (dummy) & $\begin{array}{l}0.119 \\
(1.07)\end{array}$ & $\begin{array}{l}0.109 \\
(1.86)^{*}\end{array}$ & $\begin{array}{l}1.792 \\
(1.99) * *\end{array}$ & $\begin{array}{l}0.046 \\
(0.51)\end{array}$ \\
\hline Ethereum platform (dummy) & $\begin{array}{l}0.054 \\
(0.55)\end{array}$ & $\begin{array}{l}-0.021 \\
(-0.46)\end{array}$ & $\begin{array}{l}1.557 \\
(2.49)^{* * *}\end{array}$ & $\begin{array}{l}0.025 \\
(0.52)\end{array}$ \\
\hline $\operatorname{Ln}(1+$ Token price $)$ & $\begin{array}{l}-0.019 \\
(-0.77)\end{array}$ & $\begin{array}{l}0.018 \\
(1.18)\end{array}$ & $\begin{array}{l}0.024 \\
(0.16)\end{array}$ & $\begin{array}{l}-0.023 \\
(-1.90)^{*}\end{array}$ \\
\hline $\operatorname{Ln}(1+$ Total tokens $)$ & $\begin{array}{l}0.012 \\
(0.59)\end{array}$ & $\begin{array}{l}0.041 \\
(2.59) * * *\end{array}$ & $\begin{array}{l}0.252 \\
(1.83)^{*}\end{array}$ & $\begin{array}{l}-0.003 \\
(-0.24)\end{array}$ \\
\hline Time dummies & Yes & Yes & Yes & Yes \\
\hline Observations & 185 & 575 & 630 & 630 \\
\hline F-Value & & $17.68 * * *$ & $13.53 * * *$ & \\
\hline Wald $\mathrm{Chi}^{2}$ & $44.28 * * *$ & & & $152.62 * * *$ \\
\hline (pseudo or adjusted) R-Squared & 0.233 & 0.264 & 0.229 & 0.228 \\
\hline
\end{tabular}

Note: See Table 1 for variable definitions. The first and fourth column report average marginal effects from logistic regressions with $z$-statistics using robust standard errors in parentheses. The second and third column report OLS regression coefficients with $t$-statistics using robust standard errors in parentheses. $*=$ significant at the $10 \%$ level, $* *=$ significant at the $5 \%$ level, $* * *=$ significant at the $1 \%$ level. 
Table 9: Determinants of ex-post success

\begin{tabular}{|c|c|c|c|c|}
\hline Variable & $\begin{array}{c}\text { Website } \\
\text { online }\end{array}$ & $\begin{array}{c}\text { Tweets } \\
\text { per week }\end{array}$ & $\begin{array}{l}\text { Twitter } \\
\text { activity }\end{array}$ & $\begin{array}{l}\text { GitHub } \\
\text { activity }\end{array}$ \\
\hline \multicolumn{5}{|l|}{ Independent variables } \\
\hline GitHub_preICO (dummy) & $\begin{array}{l}0.127 \\
(3.67) * * *\end{array}$ & $\begin{array}{l}1.406 \\
(0.61)\end{array}$ & $\begin{array}{l}0.076 \\
(2.02)^{* *}\end{array}$ & $\begin{array}{l}-0.045 \\
(-0.76)\end{array}$ \\
\hline Insider token retention (\%) & $\begin{array}{l}0.048 \\
(0.76)\end{array}$ & $\begin{array}{l}12.227 \\
(3.11)^{* * *}\end{array}$ & $\begin{array}{l}0.126 \\
(1.57)\end{array}$ & $\begin{array}{l}0.194 \\
(1.68)^{*}\end{array}$ \\
\hline Presale (dummy) & $\begin{array}{l}0.013 \\
(0.41)\end{array}$ & $\begin{array}{l}1.323 \\
(0.53)\end{array}$ & $\begin{array}{l}0.067 \\
(1.74) *\end{array}$ & $\begin{array}{l}-0.003 \\
(-0.04)\end{array}$ \\
\hline Bonus scheme (dummy) & $\begin{array}{l}-0.07 \\
(-2.24) * *\end{array}$ & $\begin{array}{l}-2.341 \\
(-1.06)\end{array}$ & $\begin{array}{l}-0.087 \\
(-2.31)^{* *}\end{array}$ & $\begin{array}{l}-0.073 \\
(-1.34)\end{array}$ \\
\hline Duration (\# days) & $\begin{array}{l}0.001 \\
(0.05)\end{array}$ & $\begin{array}{l}-0.102 \\
(-2.29) * *\end{array}$ & $\begin{array}{l}-0.002 \\
(-2.10)^{* *}\end{array}$ & $\begin{array}{l}-0.005 \\
(-2.83) * * *\end{array}$ \\
\hline Team members (\#) & $\begin{array}{l}0.014 \\
(5.04)^{* * *}\end{array}$ & $\begin{array}{l}0.543 \\
(3.09) * * *\end{array}$ & $\begin{array}{l}0.022 \\
(7.23)^{* * *}\end{array}$ & $\begin{array}{l}0.008 \\
(2.10)^{* *}\end{array}$ \\
\hline \multicolumn{5}{|l|}{ Control variables } \\
\hline Uncapped ICO (dummy) & $\begin{array}{l}0.028 \\
(0.49)\end{array}$ & $\begin{array}{l}1.395 \\
(0.49)\end{array}$ & $\begin{array}{l}0.056 \\
(0.79)\end{array}$ & $\begin{array}{l}0.04 \\
(0.41)\end{array}$ \\
\hline Accepted currencies (\#) & $\begin{array}{l}0.009 \\
(0.74)\end{array}$ & $\begin{array}{l}1.382 \\
(1.52)\end{array}$ & $\begin{array}{l}-0.006 \\
(-0.4)\end{array}$ & $\begin{array}{l}-0.036 \\
(-1.32)\end{array}$ \\
\hline Fiat currency (dummy) & $\begin{array}{c}-0.007 \\
(-0.11)\end{array}$ & $\begin{array}{l}13.425 \\
(2.37)^{* *}\end{array}$ & $\begin{array}{l}0.18 \\
(2.25)^{* *}\end{array}$ & $\begin{array}{l}0.161 \\
(1.18)\end{array}$ \\
\hline Ethereum platform (dummy) & $\begin{array}{l}0.048 \\
(1.19)\end{array}$ & $\begin{array}{l}3.206 \\
(1.47)\end{array}$ & $\begin{array}{l}0.045 \\
(0.86)\end{array}$ & $\begin{array}{l}-0.075 \\
(-0.92)\end{array}$ \\
\hline Ln(1+Token price $)$ & $\begin{array}{l}0.006 \\
(0.6)\end{array}$ & $\begin{array}{l}-1.078 \\
(-2.43)^{* *}\end{array}$ & $\begin{array}{l}-0.01 \\
(-0.79)\end{array}$ & $\begin{array}{l}0.028 \\
(1.56)\end{array}$ \\
\hline Ln(1+Total tokens $)$ & $\begin{array}{l}0.001 \\
(0.16)\end{array}$ & $\begin{array}{l}-0.165 \\
(-0.40)\end{array}$ & $\begin{array}{l}0.003 \\
(0.29)\end{array}$ & $\begin{array}{l}0.039 \\
(2.44)^{* *}\end{array}$ \\
\hline Time dummies & Yes & Yes & Yes & Yes \\
\hline Observations & 630 & 552 & 552 & 357 \\
\hline F-Value & & $3.11 * * *$ & & \\
\hline Wald $\mathrm{Chi}^{2}$ & $64.08 * * *$ & & $76.71 * * *$ & $42.32 * * *$ \\
\hline (pseudo or adjusted) R-Squared & 0.125 & 0.081 & 0.174 & 0.094 \\
\hline
\end{tabular}

Note: See Table 1 for variable definitions. The first, third, and fourth column report average marginal effects from logistic regressions with $z$-statistics using robust standard errors in parentheses. The second column reports OLS regression coefficients with $t$-statistics using robust standard errors in parentheses. $*=$ significant at the $10 \%$ level, $* *=$ significant at the $5 \%$ level, $* * *=$ significant at the $1 \%$ level. 